Article

\title{
Sustainable Land Use, Soil Protection and Phosphorus Management from a Cross-National Perspective
}

\author{
Jessica Stubenrauch, Beatrice Garske and Felix Ekardt * \\ Research Unit Sustainability and Climate Policy, University of Rostock, 18051 Rostock, \\ Mecklenburg-Vorpommern, Germany; jessica.stubenrauch@uni-rostock.de (J.S.); \\ beatrice.garske@uni-rostock.de (B.G.) \\ * Correspondence: felix.ekardt@uni-rostock.de; Tel.: +49-341-492-77866
}

Received: 4 May 2018; Accepted: 10 June 2018; Published: 13 June 2018

\begin{abstract}
The scarcity of phosphorus (P) is a global concern that is not restricted to western industrialized nations. Until now, most countries in the world are highly dependent on importing mineral P fertilizers for agriculture. The industrialized nation of Germany, the emerging economy of Costa Rica, and the developing country of Nicaragua are examined with regard to their legislation in the field of environmental protection and agriculture, in particular with regard to soil protection and fertilizer law. Based on the structure of agriculture in each country, control weaknesses in legislation in the individual countries, which is largely determined by command-and-control law, are identified and compared. It becomes clear that soil protection in all three countries has not yet been adequately standardised in law and at the same time the efficient use of organic or recycled P fertilizers instead of (finite) mineral P fertilizers is inadequately regulated. In particular, frugality, i.e., the strategy of lower (and not only more efficient) consumption of $\mathrm{P}$ fertilizers, has so far played no regulatory role in land-use governance.
\end{abstract}

Keywords: phosphorus; legal comparison; governance; sustainable agriculture; fertilization; soil protection; Germany; Costa Rica; Nicaragua

\section{Phosphorus and Sustainable Agriculture-Problem and Methodology}

Long-term availability of phosphorus $(\mathrm{P})$, an essential nutrient for plants, animals, and humans, is a fundamental prerequisite for ending hunger worldwide by 2030 and achieving global food security, as intended by the United Nations Sustainable Development Goals (SDGs) [1]. In order to ensure the nutrient supply of plants with $\mathrm{P}$, mineral $\mathrm{P}$ extracted by mining is still being used and to an increasing extent worldwide. In 2017, an estimated 263,000 tons of phosphate rock were mined worldwide, more than in any year before [2] (p. 123). In this context, it is interesting to take a comparative look at countries with very different agricultural and legal system requirements. Particularly, the research is intended to be an interdisciplinary study into sustainability research from a humanities perspective. Existing legal approaches of countries that differ in geographic and socioeconomic terms are examined, focussing on $P$ resource conservation and the protection of related natural resources, such as soil, water, climate, biodiversity. The research aims to identify specific but above all recurring shortcomings in legislation as reasons for the unsustainable use of the aforementioned resources. Therefore, this comparative study can be seen as a first step to further develop effective governance for the sustainable use of $P$ in agriculture and the protection of natural resources on national, supranational or international levels that are able to overcome the identified legal inefficiencies.

All countries in the world face the same future challenge: to develop sustainable agriculture systems which produce a sufficient amount of healthy food and at the same time preserve natural resources. SDGs have a universal character and apply equally to all countries [1] (p. 3); Nicaragua as a 
developing country, the emerging economy Costa Rica, and Germany as a typical industrialized nation have been selected for the legal comparison. While the use of mineral $P$ fertilizers is tending to increase in Costa Rica and Nicaragua, it is rather stagnating at a medium level in industrialized countries such as Germany [3,4]. In 2015, Costa Rica had an average mineral P use per area of cropland of $41.23 \mathrm{~kg}$ $\mathrm{P}_{2} \mathrm{O}_{5} / \mathrm{ha}$, well above the global average of $30.1 \mathrm{~kg} \mathrm{P}_{2} \mathrm{O}_{5} / \mathrm{ha}$. Nicaragua, on the other hand, is far below the global average at $9.74 \mathrm{~kg} \mathrm{P}_{2} \mathrm{O}_{5} / \mathrm{ha}$-although the climatic and biophysical conditions are largely the same as in Costa Rica-while Germany's consumption of $23.87 \mathrm{~kg} \mathrm{P}_{2} \mathrm{O}_{5}$ /ha is slightly below the global average [3]. For this reason, there is also a special interest in this comparative analysis of countries. The deposits of phosphate rocks, however, are firstly finite. There is a limit in the economic sense, i.e., phosphate reserves are (operationally) economically extractable according to the current state-of-the-art and at today's prices. According to data from the U.S. Geological Survey from 2017, the statistical range of phosphate reserves, which is the quotient of available reserves and the extracted phosphate rock, is 266 years [2] (p. 123). Secondly, phosphorus is limited to only a few regions of the earth, which results in an import dependency in the vast majority of countries [5-7]. This import dependency of $\mathrm{P}$ is already problematic because the highly monopolized market structure impedes effective price control for raw phosphates [8,9].

In the event of external shocks, such as the 2008 food crisis, the price of mineral P fertilizers may rise unexpectedly and disproportionately [10]. Particularly in developing countries and emerging economies where farmers tend to be poorer, price fluctuations are more difficult to deal with; as such, in a worst-case scenario, the supply of $P$ to plants cannot be guaranteed and the risk of crop losses increases due to a lack of alternatives [11]. Above all, geopolitical risks with regard to export countries that are difficult to predict also endanger the secure supply of $P$ fertilizers in industrialized countries. At present, a medium supply risk is assumed for $\mathrm{P}$ due to geopolitical instability in Morocco, one of the dominant exporters in the market [12].

In addition, the use of mineral $\mathrm{P}$ fertilizers in agriculture is directly linked to negative environmental impacts such as soil degradation, biodiversity loss, and global climate change. Firstly, heavy metals such as cadmium (Cd) and uranium (U) are increasingly being introduced with the mineral $\mathrm{P}$ fertilizer into the soil, which causes potential soil degradation [13]. Secondly, the predominant use of mineral fertilizers can lead to a long-term loss of soil organic matter. This is particularly true in connection with intensive, monocultural soil management with rapid crop rotation, lack of intercropping and continuously high removal rates of biomass from the field [14] (p. 45), [15]. Along with the loss of soil organic matter, soil biodiversity, water infiltration rate, and natural soil fertility decrease simultaneously [14]. At the same time, the lower water absorption capacity of the soil increases the risk of erosion, causing nutrients and pollutants to be more easily discharged into neighboring ecosystems, thus accelerating the eutrophication of water bodies [16-20]. Due to the loss of soil organic matter, the sink function of the soil as a global carbon store decreases as well, so that the potential to help mitigate global climate change is reduced [21]. Finally, the soil's ability to cope with crises-e.g., due to extreme weather events that are likely to occur more frequently in the future-is severely reduced [22-24]. The potentially mutual reinforcement of various environmental problems, which are also linked to fertilization, is already becoming clear. In the future, managing the soil sustainably also means circulating nutrients like $\mathrm{P}$ and replacing mineral $\mathrm{P}$ fertilizers obtained from mining with fertilizers from organic materials or recycled $P$ fertilizers, preferably regionally produced using renewable energy [25-28].

On this basis, this paper asks to what extent legislation has so far effectively addressed this situation. Supported by a brief analysis of the natural scientific data, a methodical and comparative legal analysis of deliberately selected contrasting countries is carried out. Legal texts from different legislative fields are compared, whereby the basis for text comprehension are legal interpretation methods as practiced worldwide (the focus here is on the literal sense and systematics of legal norms) [29] (pp. 83-95). Comparative legal studies are a recognized method for gaining scientific knowledge $[30,31]$. The legal comparison provides "insights into the interrelationships, processes, 
causes and recurrent patterns of reality" [30] (p. 1084). In this way, lessons can be learned from the Latin American legislation [30] (p. 1084). In order to reflect the different contextualization of Latin American legislation [31] (p. 187), expert interviews were conducted in Nicaragua and Costa Rica during a three-month research stay from September to December 2016. Eight interviews were conducted in Costa Rica and six in Nicaragua with stakeholders from the agricultural administration, universities, agricultural associations and farmers. In particular, the openly structured interviews provided different perspectives, which served to better assess the actual implementation and application of existing legislation. The evaluation of the content of the interviews was therefore qualitative [32] and served as a supplement to the legal text analysis.

If the possible, ecological regulatory effects are considered, thus further extending the pure legal comparison in substance by aspects of legal effectiveness, control and governance research. This is limited in the present case to the extent to which the legal requirements laid down fit the officially pursued, overall objectives, in particular of international environmental law [29] (pp. 74-83).

\section{Key Characteristics of the Agricultural Sector in Germany, Costa Rica, and Nicaragua}

In German agriculture, the largest share of added value (almost 50\%) is achieved through intensive livestock farming [33] (p. 8). Increasing export surpluses are generated for all types of meat [34]. An area-bound livestock farming - which would facilitate a recirculation of $\mathrm{P}$-is mandatory in organic farming only (Art. 4 and Art. 14 Para. 1 lit. (d) No. (i) Regulation (EC) No. 834/2007). Although the total share of organic farming in Germany accounts for $7.5 \%$, not all have integrated livestock farming [35] (p. 46). In total, only 14\% of all agricultural holdings are integrated farms, which combine agriculture and livestock farming in different proportions [33] (p. 8). The number of farms fell by 40,800 to 280,800 between 2010 and 2015, with a particularly sharp decline in small livestock holdings [36]. In regions of intensive livestock farming, large quantities of animal feed must be imported, while remaining manure surpluses place a heavy burden on water quality (The European Commission has already initiated an infringement proceeding (Case C-543/16) against Germany due to high nitrate inputs into water bodies and groundwater bodies). Germany imports around 80 million hectares of virtual land each year for food and animal feed and thus indirectly tons of P [37]. Due to the overall increase in land use pressure, permanent grassland ( $29 \%$ of agricultural land) is also predominantly intensively used and fertilized, with negative consequences for soil, water, biodiversity and climate protection [38] (p. 9). Even though on average, P balance surpluses in German soils have been declining since 2000 by $5 \mathrm{~kg} \mathrm{P} /$ ha annually, there are still nutrient hotspots often linked with spatially concentrated, intensive livestock farming. These hotspots stand in contrast to regions with nutrient deficits mainly due to low livestock density.

In the emerging economy of Costa Rica, about $47 \%$ of the total land area, which with $51,100 \mathrm{~km}^{2}$ roughly corresponds to the size of Lower Saxony, is currently used for agriculture [39] (p. 24). Agriculture is particularly oriented towards exports. Currently $64 \%$ of agricultural land is used exclusively to grow export crops such as coffee, palm oil, sugar cane, bananas and pineapples [40] (p. 19). In particular, the small landholder subsistence economy has lost importance in favour of the export economy [41] (p. 7), [42] (p. 3). The number of agricultural holdings decreased by around $60 \%$ between 1984 and 2014, reaching 93,017 in 2014 [39] (p. 33), [43] (p. 185). Less than 5\% of farms are dedicated to the production of basic foodstuffs [39] (p. 38). Cereals, beans and rice-at the expense of food security in the country - therefore largely need to be imported from the world market [39] (pp. 171-173). At the same time, Costa Rica is the world's leading exporter of pineapples and, with 63,383.2 kg pineapple production per hectare in 2014, achieved the highest yield in Latin America on average [44]. An extremely high use of mineral fertilizers (and pesticides) characterizes the intensive, monocultural cultivation of tropical fruits and is therefore an important driver for soil degradation and the destruction of neighboring ecosystems [45-47]. Accordingly, compared to Germany and Nicaragua, Costa Rica has the highest average consumption of mineral $\mathrm{P}$ fertilizers per hectare of agricultural land, which is accompanied by one of the highest levels of chemical pesticide usage in the world $[3,48]$. 
Pastures (43\% of the agricultural area) are also increasingly intensively used and fertilized, using mainly mineral fertilizers. Costa Rica's soils tend to have a deficiency of plant available P. This is particularly true for soils of volcanic origin or deeply weathered red tropical soils, with active iron and aluminium oxides restricting plant available P [49] (p. 8), [50].

In the developing country Nicaragua, agriculture has traditionally been of great economic importance [51,52]. The share of agricultural products in Nicaragua's total exports from January to July 2017 was over $80 \%$ and is planned to be increased in the future [53]. The main agricultural export products are coffee, beef and sugar [54] (p. 4). Still, in terms of labor productivity and average agricultural yield per hectare, Nicaragua ranks last in Central America [55] (p. 36). Accordingly, the usage of mineral $P$ fertilizer is the lowest in the countries compared in this study, even though average P use per area of cropland showed a rising trend in 2014 and 2015 [3]. Agricultural land is still distributed among more than 300,000 producers [56], of which over $80 \%$ are small farmers, who cultivate less than 5 ha of land and use mineral $P$ fertilizers according to their financial abilities and depending on risk factors such as local weather conditions [57] (p. 69), [58]. In 2014, during the rainy season (May to November), up to $50 \%$ less rain fell locally than in previous years [59] so that many small farmers refrained from using expensive mineral fertilizers or changed their production (e.g., from peanuts to millet and sesame, which require less mineral P fertilizer) [60]. However, above all, uncertain land rights allow the almost unimpeded spread of industrial palm oil, sugar cane or peanut production by major investors because small scale farmers cannot adequately defend their ownership of land (which is partly only customary and not titled or registered in the cadastre) $[57,61,62]$. This industrial production is regularly accompanied by a high consumption of mineral fertilizers [62] (p. 4). Extensive livestock farming, which is characterised by extremely high land consumption, is spreading almost unchecked in Nicaragua as well [62] (p. 5) [63], even though the majority of pastures are not (yet) additionally fertilized. Nonetheless, livestock farming is, once again, largely decoupled from plant production at the expense of soil, forests, biodiversity and climate protection [63]. Overall, about 40 tons of soil per hectare are eroded every year due to farming methods that are not adapted to the site in Nicaragua [62] (p. 5). Regarding P, Nicaragua's tropical soils tend to be undersupplied with plant-available P [64], as is the case with Costa Rica.

\section{Results from the Legal Comparison}

\subsection{International Level}

International, openly formulated, legally non-binding declarations of intent-such as the SDGs-dominate with regard to the sparing use of $(\mathrm{P})$ resources in agriculture and soil protection. A binding international agreement explicitly aimed at limiting the use of mineral $\mathrm{P}$ fertilizers in agriculture and using P more efficiently does not exist. Nevertheless, on the basis of internationally binding agreements on environmental protection and on the basis of human rights obligations, the importance of improved P management in agriculture can be determined [29] (pp. 217-223). Germany, Costa Rica, and Nicaragua have ratified the following agreements:

- The Convention on Biological Diversity (CBD) [65], which came into force on 29 December 1993;

- The United Nations Convention to Combat Desertification in those Countries Experiencing Serious Drought and/or Desertification, particularly in Africa (UNCCD) [66], which came into force on 26 December 1996;

- $\quad$ The Paris Agreement (PA) [67,68], which came into force on 4 November 2016.

Art. 1 of the CBD pursues the legally binding objective of conserving biological diversity and using its components sustainably. P losses from agricultural used soils and their leakage to inland and coastal waters are one major driver for the eutrophication of water bodies [69], thus restricting aquatic biodiversity [70,71]. In addition, soil biodiversity can be significantly decreased by intensive farming methods, which are accompanied by a high use of mineral $(\mathrm{P})$ fertilizers and pesticides [72,73]. Thus, 
controlling the use of (mineral) $\mathrm{P}$ fertilizers in order to combat eutrophication of waterbodies and to preserve soil biodiversity becomes a major issue to fulfil the CBD. The UNCCD provides for combating desertification and mitigating the effects of drought through effective action at all levels to contribute to the achievement of sustainable development in the affected areas [66] (p. 6). Nicaragua and Costa Rica are among the affected countries specifically addressed by the UNCCD. The establishment of a sustainable, site-adapted, circular economy requires congruent agricultural systems to be generated for $\mathrm{P}$ [74]. Therefore, protecting the soil and preventing nutrient and pollutant leakage into neighboring ecosystems is directly linked to the fulfilment of these two international agreements. In particular, the circular economy concept in agriculture aims to stimulate the rational use of organic fertilizers from the farm or recycled from biowaste or other secondary raw materials [28] and thus helps to preserve biodiversity and healthy soils with a high natural soil fertility.

The PA obliges the international community pursuant to Art. 2 para. 1a PA to limit global warming to "well below" $2{ }^{\circ} \mathrm{C}$ (and if possible even to $1.5^{\circ} \mathrm{C}$ ) compared to pre-industrial levels; however, this requires globally timely and drastic emission reductions with the objective of achieving zero emissions on the one hand [25], [26] (p. 6), [27] (p. 36), [75] and the preservation of the soil's sink function as a carbon reservoir [20] on the other hand. Hence, a rather short-term exit from fossil fuels is also necessary in the agricultural sector [76]. Worldwide, the share of greenhouse gas emissions from agriculture, forestry and other land use (AFOLU) is about a quarter [27] (p. 47), [76]. Regarding mineral $\mathrm{P}$, mining and transport are directly linked to the consumption of fossil fuels [77]. However, the climatic relevance of mineral fertilization is further exacerbated by the energy-intensive production of nitrogen (N) [78] (p. 74), [79], particularly because $\mathrm{N}$ is often applied in combination with $\mathrm{P}$ and/or potassium (K) as NPK fertilizer to the soil. In Germany, for instance, over $90 \%$ of mineral fertilizers are sold as complex fertilizers [80].

Most importantly though, zero-emissions and the preservation of biodiversity, water and soils require a drastic reduction of animal food production and consumption [73,81]. According to the Food and Agriculture Association (FAO) 33\% of total arable land is used exclusively for animal feed production [82] (p. xxi). Raschka et al. even estimate the share of total arable land for the production of animal feed to be $71 \%$ in their study [83] (p. 21). However, the mostly monocultural, industrial feedstuff production is usually combined with a high mineral $(\mathrm{P})$ fertilizer input [84]. According to the International Fertilizer Association, due to "firm demand from the livestock sector" [84] (p. 1) oilseed production will increase in the future and is therefore one driver for the expected increase in global demand for mineral P [84] (p. 2). Thus, by reducing demand for feedstuff, e.g., soy, mineral P fertilizer consumption may be reduced as well. Notwithstanding this, due to a minimised livestock production required in the future, the supply of organic fertilizers (including P) will be significantly restricted as well. This is especially the case since the general transformation of the energy sector towards renewables is also combined with the use of animal manure for bioenergy production [85]. Thus, in order to prevent a higher demand for mineral $\mathrm{P}$ fertilizers in the aftermath, mixed farming models with an area-bound livestock farming, that are optimally adapted to the site-specific conditions [86] (p. 160) and include practices like cereal/legume intercropping [87] that enhance natural soil fertility must be stimulated by appropriate policy instruments [88], [89] (pp. 40, 135). However, in order to achieve the necessary worldwide reduction in meat consumption, which, as has been shown, is closely linked to the challenge of closing $\mathrm{P}$ fertilizer cycles in the future, would require behavioural changes i.e. frugality, and must be triggered by appropriate policy instruments. The requirement for an overall reduction in livestock farming that is also optimally adapted to the area, is not contradictory, since intensive livestock farming systems keep livestock numbers far beyond the locally available farmland capacity (see also Section 2 the case of Germany) [77]. Overall, this indicates a total revision of previous agricultural concepts, which were rather based on further intensification and specialisation instead of site-adapted integrated crop-livestock systems [71,88,90]. 


\subsection{Constitutional Anchoring of Environmental and Resource Protection Law at the National and European Level}

The adoption of frugality as well as efficiency (the more efficient use of resources) and consistency (the reuse of resources) includes the un-popular measure of lowering consumption and is thus politically complex. However, whether or not natural $(\mathrm{P})$ resources must be sustained is not left to the political discretion of states. Besides a legal obligation to prevent climate change, a duty to prevent the loss of biodiversity and the degradation of soil and water pollution can be derived also from fundamental rights [29] (pp. 255-262). In particular, among the prerequisites for a free life in dignity are the sufficient availability of water, food and air [29] (pp. 255-262). Since P is an essential nutrient for plants, animals and humans and inappropriate $\mathrm{P}$ fertilization causes negative effects on the environment (eutrophication of water bodies, soil degradation, e.g., due to heavy metal inputs) the usage of $\mathrm{P}$ in agriculture is therefore linked to the fulfilment of fundamental rights. This applies in particular if intensive agricultural practices combined with a high mineral $P$ fertilizer input could ultimately lead to a collapse of the Earth system by endangering its physical foundations, such as a stable climate, healthy soils, sufficient water, and biodiversity [29] (pp. 223, 328-330), [91].

Therefore, it has been shown repeatedly that in international, European, and national law, a relevant constitutional protection results from fundamental rights considerations regarding the right to life, health and a minimum subsistence level including a right to food [29] (pp. 194-375), [92-94]. However, legal practice has largely ignored this so far, since the problems caused by $\mathrm{P}$ have not yet been recognized. Among the less stringent objectives such as in the German constitution (Art. 20a GG) or the EU primary law in Art. 37 of the EU Charter of Fundamental Rights (CFR), and Art. 11 of the Treaty on the Functioning of the European Union (TFEU) [95] (p. 93), [96] (p. 173) statements such as those contained in Art. 191 TFEU (objective of prudent and rational utilisation of natural resources) can be found. However, no tangible restrictions on the use of scarce resources such as P or the soil exist.

Article 50 of the Costa Rican Constitution lays down the "right to a healthy and ecologically balanced environment" together with the right of individuals to report violations to the environmental tribunal. According to the 2015-2018 National Development Plan, the right to food and nutrition sovereignty is to be written into the constitution [97] (p. 291). Since fundamental environmental obligations have so far tended to be overlooked by a variety of states, it remains to be seen whether this will change anything in reality. Costa Rica's strong export orientation in particular runs counter to the right to food sovereignty, defined as "the right of people to produce, distribute and consume healthy food in and near their territory in an ecologically sustainable manner" [98] (p. 588).

The Nicaraguan constitution of 1987 was last reformed in 2014, enabling the reelection of the president (Daniel Ortega). At the same time, Art. 60 of the Nicaraguan Constitution was extended [99]. Based on Art. 60, the obligation arises for all inhabitants to maintain a clean environment and to protect it and its natural resources. In addition, "Mother Earth" (in Spanish "madre tierra", where "tierra" can have two meanings "world" and "soil") and all life-sustaining natural processes, thus also a healthy soil, next to the explicitly mentioned biodiversity is of particular importance. The earth is attributed dignity as an independent, living object. "It is to be loved, to protected and to regenerated" (Art. 60 Nicaraguan Constitution). The Nicaraguan people must adopt consumption and production practices that guarantee the vitality and integrity of the earth, with particular emphasis on the integrity of ecosystems and biodiversity. The social equality of people and responsible consumption based on solidarity and good coexistence must be achieved in accordance with Art. 60 of the Nicaraguan constitution. At the same time, Art. 60 of the Nicaraguan constitution refers to the Universal Declaration of the Common Good of the Earth and Humanity [100]. This Declaration (Declaración Universal del Bien Común de la Tierra y de la Humanidad) has been drawn up as a supplement to the Universal Declaration of Human Rights. The need to reduce means of production and goods of consumption, to reuse products and to collect and recycle waste is emphasized), which was signed by Nicaragua on 6 February 2010 (as the first country to do so) but has not yet become valid internationally due to a lack of states that have ratified the declaration [101]. Art. 102 of the Nicaraguan 
constitution obliges the state to protect natural resources and to use them rationally, but according to the national interest.

With regard to resource protection and the use of natural resources, it is interesting that although the obligation to protect resources has a human rights basis (due to the binding character of international treaties on human rights and the respective constitutions) it is still ignored more or less everywhere. With regard to the fact that the European and the German jurisdiction accepts environmental fundamental rights in theory but do not draw any consequences from these rights in reality, see Ekardt 2018 [102] and Calliess 2001 [93]. However, it can be derived directly from Art. 60 of the Costa Rican Constitution and was incorporated into Art. 102 of the Nicaraguan constitution as well. Furthermore, Nicaragua is the only country that has included the necessity to implement frugality in its constitution and therefore is very progressive in this respect. Due to the lack of enforceability by the courts in Nicaragua a targeted practical implementation of all this is again not discernible.

\subsection{Environmental and in Particular, Soil Protection Legislation}

\subsubsection{EU and Germany}

In addition to the above-mentioned binding international objectives in the climate and biodiversity sector, EU agricultural and environmental legislation has a major influence on national agricultural practices and thus on $\mathrm{P}$ use and the level of environmental protection in the member states. First, the EU Nitrates Directive [103] requires member states to encourage Good Agricultural Practices and to adopt action programmes in order to reduce water pollution from $\mathrm{N}$ compounds from agricultural sources and to prevent further water pollution [104] (p. 10). Good Agricultural Practices include inter alia periods during which fertilizers should not be applied to agricultural land or rules on procedures for the application of fertilizers (Annex II of the Nitrates Directive). In addition to the mandatory rules on nitrate fertilization, some EU member states, such as Ireland and the Netherlands, have also introduced limits for P. This has improved fertilization practice in some areas in recent decades, albeit with large differences between EU member states in both the P and N-balance [105] (pp. 4-5). Nevertheless, $\mathrm{P}$ is not specifically the focus of the directive. Besides the EU Nitrates Directive is an important instrument for implementing the EU Water Framework Directive (WFD) [106]. Art. 4 para. 1 WFD obliges EU Member States to achieve a good ecological and chemical status of surface waters and a good quantitative and chemical status of groundwater bodies by 2027 at the latest. The WFD also mentions P compounds as pollutants for water bodies [106] (p. 46), although, a clear reference to $\mathrm{P}$ fertilization is also missing here. $\mathrm{P}$ has been included in the WFD list of agri-environmental indicators describing the main impacts on water quality. However, due to limited data availability and methodological difficulties, the indicator is not yet considered applicable.

A further key component of European agricultural legislation is the Common Agricultural Policy (CAP). To receive direct payments within the framework of the first pillar of CAP, farmers have to comply with cross-compliance rules. According to Regulation (EU) No. 1306/2013 [107], these rules include standards for good agricultural and environmental conditions (GAEC) which potentially contribute to the reduction of $P$ losses in agriculture [108]. For example, standards for better soil management reduce soil erosion and the loss of soil organic matter and thus minimize P losses [109] (p. 15). The regulations, however, are not explicitly aimed at $P$ and there is no obligation for farmers to limit P use within the cross-compliance system [110] (p. 26). In fact, cross-compliance is merely a basic requirement for environmental and resource protection, which is not sufficient to develop truly sustainable and circular economy based agricultural systems. Hence, most subsidies continue to be paid for unsustainable farming methods and thus the CAP does not contribute adequately to the protection of natural resources such as soil or biodiversity [111,112]. This continues to remain valid after the reform of the CAP in 2013 [111,112]. The Greening introduced in this context aimed to make the EU agricultural sector more environment-friendly by having direct payments to farmers more closely linked to environmental services, in particular: crop diversification, the maintenance of 
permanent grassland, and the creation of ecological focus areas (Art. 43 para. 2 Regulation (EU) No. 1307/2013) [113]. But it is up to the EU member states whether or not they use their considerable scope for implementation of more sustainable agricultural practices. In particular, the political will of the EU member states strongly influences the design of agricultural environment programmes within the framework of rural development policy [114]. The second pillar of CAP can certainly contribute to reducing $\mathrm{P}$ losses in agriculture if an appropriate focus is set. So far, this is still lacking. In addition, the second pillar is chronically underfunded $[115,116]$. The extent to which the CAP can develop an enhanced influence on more sustainable $\mathrm{P}$ management in the future will therefore depend primarily on its further revision by 2020 .

In addition to the national implementation acts of the CAP, various areas of environmental law show potential impact on the P problem in Germany. First of all, the Federal Nature Conservation Act (BNatSchG) [117] in $\S 1$ para. 3 No. 2 BNatSchG initially stipulates that soils must be preserved so that they can fulfil their ecosystem functions. The BNatSchG is concretised by the laws for the protection of soils, water and air among other sector-specific laws [118]. However, the water protection provisions of the Federal Water Act [119], which implements the objectives of the European Nitrates Directive and the WFD, as well as the Federal Emission Control Act [120], which implements the European Directive on the reduction of national emissions of certain atmospheric pollutants (NEC Directive) [121] and the Air Quality Directive [122], are not applicable to agricultural land use. The same applies to the Federal Soil Conservation Act (BBodSchG) [123]. In the absence of an European Soil Framework Directive [124-126] the BBodSchG aims at the protection and restoration of sustainable soil functions ( 1 BBodSchG).

With regard to agricultural soil use, the principles of Good Agricultural Practice are introduced in $\S 17$ BBodSchG. Good Agricultural Practice includes, for example, site-adapted soil cultivation, and the promotion of biological activity through appropriate crop rotation management. Yet according to $\S$ 3 para. 1 BBodSchG, soil protection law is subsidiary and it only applies if the waste legislation, the sewage sludge ordinance, the fertilizer and plant protection legislation, the construction and planning law and the emission protection legislation, do not already regulate the effects on the soil. This makes the fertilizer law primarily relevant for $P$ inputs (see Section 3.4), while subsidiarity keeps the steering effect of soil protection and other environmental laws with regard to $\mathrm{P}$ and sustainable land use low.

\subsubsection{Costa Rica}

Already in the Basic Act on the Environment No. 7554 of 1995 [127], with the objective of maintaining a healthy and ecologically balanced environment, general requirements for the protection of biodiversity (Art. 46 ff.), forests (Art. 48 ff.), air (Art. 49), and water (Art. 50 ff.) are determined. In addition, requirements for the protection of soils are made (Art. $53 \mathrm{ff}$.). According to Art. 53a Law 7554 , a balance between the natural potential for soil use and the economic production capacity of the soil should be established. Soil management practices that cause erosion (and thus also promote the discharge of $\mathrm{P}$ into neighboring ecosystems) or other forms of soil degradation must be controlled in accordance with Art. 53b Law 7554 as well as the use of chemical and radioactive substances (Art. $60 \mathrm{f}$ Law 7554). Agricultural practices that contribute to soil and water protection must be encouraged (Art. 53c Law 7554). The principles laid down by Law 7554 serve as a framework for the sector-specific laws and their implementing ordinances. An important tool is the Environmental Impact Assessment (EIA) for new projects that show a potentially negative impact on the environment. According to the definition in Art. 3 No. 3 ICW No. 16 of the Implementing Ordinance to Law 7554 [128], however, "new projects" in agriculture are only given in the case of land use changes. The purchase of small, formerly agriculturally used areas and their conversion into large, monoculturally cultivated areas, as is often the case with industrial pineapple cultivation, is not covered by this. Therefore, no steering effect can be achieved with regard to sustainable agricultural land use, in particular a possibly lower use of mineral $(\mathrm{P})$ fertilizers and pesticides is not encouraged. 
The Soil Conservation Act of 1998 No. 7779 [129] further specifies the regulations for sustainable land use and the restoration of degraded soils. Art. 2 Law 7779 provides for a regular inventory of soils to balance the natural soil potential and economic production capacity of the soil. Agroecology is also to be promoted in order to reconcile agricultural production with the protection of resources, soil, and water $[130,131]$. The Ministry of Agriculture and Livestock (MAG) should create a national land management and soil protection plan with binding guidelines on agricultural land use (Art. 7 ICW Art. 11 Law 7779). Every two years, the national plans are to be reviewed and adapted to current circumstances (Art. 14 Law 7779). Art. 12 of Law 7779 specifies the objectives of the national land management and soil protection plan. The aim is to achieve: an increased vegetation cover and water infiltration rate; an improved runoff regime and reduced soil contamination; a soil management system that promotes natural soil fertility by maintaining the organic matter of the soil.

These objectives are conducive to avoiding soil degradation, reducing nutrient leakage, and thus minimise the need for (mineral) $P$ fertilizers in agriculture [132]. In addition to the national soil protection plan, regional soil protection and restoration plans are to be drawn up (Art. 15 Law 7779). Their objectives according to Art. 16 Law 7779 are: to define sensitive soils based on water catchment areas, to submit proposals for the best possible type of soil use, to carry out basic soil investigations for the soil cadastre, and to develop strategies that ensure adequate soil use in each case.

According to Art. 19 Law 7779, the practices for land use, which are to be made binding by the regional soil plans, must also include the handling of (mineral) fertilizers and pesticides in accordance with the technical recommendation of the MAG as well as strategies for organic fertilization and erosion control. MAG together with the Ministry of the Environment and Energy (MINAE) are also responsible for regulating and controlling agricultural inputs and machines and equipment used (Art. 30 Law 7779). It would therefore be conceivable—given the sensitivity of the site due to a high probability of soil erosion or the threat of nonreversible soil degradation-to restrict or even prohibit the use of rapidly soluble mineral (P) fertilizers (and pesticides) on the basis of the binding regional soil protection and restoration plans.

However, research into the implementation and application of the Soil Protection Act has shown that neither the national land management and soil protection plan nor regional soil protection and restoration plans-with the exception of the central region of Costa Rica-have been fully developed to date [133]. A steering effect with a view to a site-adapted agricultural land use and a reduced use of mineral P fertilizers thus cannot be achieved.

\subsubsection{Nicaragua}

The Basic Act on the Environment and Natural Resources No. 217 of 1996 [134,135] pursues the overall objective of maintaining a clean environment (atmosphere, biodiversity, soil, and water) and protecting natural resources (Art. 1 Law 217). Soils should be used according to their natural conditions, such as physical and chemical properties and the resulting production capacity, while maintaining their natural balance (Art. 105 Law 217). Practices that promote soil erosion or degradation or negatively affect the topographical and geomorphological properties of soils should be avoided. In case of severe land degradation, the Ministry of Agriculture (MAG), in consultation with the Ministry of Environment and Resources (MARENA) and the governments of the autonomous territories of Nicaragua, may designate soil protection areas and restrict their use (Art. 107, Law 217). However, this optional provision applies only if land degradation has already occurred. Nicaragua does not have a sector-specific law for soil protection and thus also not for the prevention of soil degradation through agricultural use.

To achieve the objectives laid down in the Law 217, a national environmental plan, the designation of protected areas and national parks, environmental impact assessments, payments for ecosystem services, or subsidies from the National Environmental Fund [135], are named as instruments (Art. 11 Law 217). The Environmental Fund has been linked to existing sector-specific laws such as the National Forest Act [136] or the National Water Protection Act [137]. Since there is no specific national soil 
protection act, no corresponding connection can be established. As a consequence, with regard to soil protection, no concrete implementation, control or sanction mechanisms are formulated, although the obligation for sustainable use of the soil has been constitutionally reestablished. Thus, the principles of soil protection laid down in the constitution are not transposed into simple national law and therefore remain ineffective.

\subsubsection{Conclusions from a Comparative Legal Perspective}

The legal studies of environmental law in the individual countries show that environmental and specifically soil protection law is de facto inadequate in all three countries. In particular, soil protection is severely neglected in Germany. Firstly, because unlike in the field of water protection, a European Soil Framework Directive does not exist [138]. Thus, national soil protection law applies, which however is subsidiary to various sector-specific-laws, such as the fertilizer law, that hardly protects agricultural soils due to a traditionally strong focus on economic productivity, disregarding the natural utilisation potential and sensitivity of soils [108] (see also Section 3.4). Secondly, European CAP has a major influence on practices of land management by German farmers and their $(\mathrm{P})$ fertilizer use but is not yet sufficiently oriented towards environmentally friendly and resource-conserving agricultural practices. Other European directives only refer to individual pollutants such as $\mathrm{N}$ or do not consistently include appropriate agricultural land use in order to protect the soil or to encourage recirculation of the scarce resource $P$ in the future.

In Costa Rica, a lack of implementation of the Soil Conservation Act renders soil protection law ultimately toothless, while other environmental protection provisions of the Basic Act on the Environment do not explicitly include agricultural land use. The corresponding preference for intensified agricultural production over soil protection becomes particularly evident in the recently created exemption for agriculturally used soils as new projects within the framework of the EIA However, the same can be observed for the EIA at the European level, which has been established since 1985 [139] and imposes no requirements for the articulation of alternatives to the project under consideration in case of agricultural land use [140] (p. 168) and the Nicaraguan EIA which does not include agricultural land use from the outset [141,142].

In Nicaragua, the overarching objectives for soil protection have not yet been sufficiently specified and thus cannot be applied. Soil protection measures can only be considered once harmful soil changes have already occurred—and are not even then mandatory. Agricultural land use, including (P) fertilization, therefore does not have to follow the maxim of soil protection.

It can be concluded that although the laws on soil protection are designed in different manners or are implemented to different degrees in the individual countries, soil protection is ultimately not lent the attention it deserves. In particular, agricultural land use and the use of $(\mathrm{P})$ fertilizers as a major potential threat to soil quality are not consistently incorporated in soil protection legislation.

\subsection{Fertilizer Legislation}

\subsubsection{Product-Related Fertilizer Legislation}

Next, specific fertilizer legislation is considered. Mineral fertilizers require registration and approval in accordance with product-related fertilizer legislation. In Germany, the Federal Ministry of Food and Agriculture (BMEL) is entrusted with the approval of new fertilizers. The requirements of the Fertilizer Ordinance, DüMV [143] apply. The DüMV regulates the authorisation of fertilizers which are not designated as "EC-fertilizers", which are all fertilizers that are regulated by the EC Fertilizer Regulation 2003/2003 [144] (§ 2 Para. 1 DüMV). These must correspond to a type of fertilizer approved by the ordinance ( $\S 3$ Para. 1 DüMV) and must comply with requirements regarding nutrient and pollutant contents. For fertilizers from waste streams, corresponding quality and hygiene regulations from special laws such as the Sewage Sludge Ordinance (AbfKlärV) [145] or the Biowaste Ordinance (BioAbfV) [146] apply. Furthermore, the new AbfKlärV requires larger sewage treatment 
plant operators to recover P from sewage sludge prospectively ( 3 AbfKlärV). Mineral fertilizers can also be marketed under the already mentioned EC Fertilizer Regulation 2003/2003 [144], which is currently being extensively amended, inter alia, to include and promote fertilizers from organic materials, recycled bio-waste or recycled P from sewage sludge [147].

In Costa Rica, registration for mineral fertilizers is handled by the State Plant Protection Agency (SFE) in accordance with the Plant Protection Act No. 7664 [148]. In Nicaragua, the Institute for the Protection and Health Monitoring of the Agricultural Sector (IPSA) is responsible for the registration and quality control of agricultural inputs in accordance with the Basic Law on Animal and Plant Health No. 291 [149] as an independent institution (Art. 2, 37, Law 291). In addition, a Central American technical implementation regulation [150] exists, which regulates basic requirements for the registration of fertilizers in Costa Rica, Nicaragua, El Salvador, Guatemala, and Honduras.

Mineral $P$ fertilizers extracted from mines are increasingly contaminated with heavy metals like $\mathrm{U}$ and $\mathrm{Cd}$ [151]. While no limit values exist for $\mathrm{U}$, certain maximum values per kilogram of $\mathrm{P}_{2} \mathrm{O}_{5}$ are specified for Cd (see Table 1).

Table 1. Limit values for $\mathrm{Cd}$ in the case countries.

\begin{tabular}{ccc}
\hline Region & Regulation & Limit Value \\
\hline Europe & EC 2003/2003 & no limit for Cd \\
Germany & DüMV & $50 \mathrm{mg} / \mathrm{kg} \mathrm{P}_{2} \mathrm{O}_{5}$ \\
Central America & RTCA 65.05.54:09 & no limit for Cd \\
Costa Rica & RTCR 485:2016 [152] & $80 \mathrm{mg} / \mathrm{kg} \mathrm{P}_{2} \mathrm{O}_{5}$ \\
Nicaragua & RTCA 65.05.54:09 & no limit for Cd \\
\hline
\end{tabular}

In particular, phosphates from sedimentary phosphate deposits usually contain an average value of over $60 \mathrm{mg} \mathrm{Cd} / \mathrm{kg} \mathrm{P}_{2} \mathrm{O}_{5}$, with maximum values of over $80 \mathrm{mg} \mathrm{Cd} / \mathrm{kg} \mathrm{P}_{2} \mathrm{O}_{5}$ possible [153-155]. There is a relatively high risk of $\mathrm{Cd}$ being transferred to the plant or groundwater, especially in combination with $\mathrm{Cd}$ concentrations above $60 \mathrm{mg} \mathrm{Cd} / \mathrm{kg} \mathrm{P}_{2} \mathrm{O}_{5}$, low $\mathrm{pH}$ values (below 6.5) or low organic matter content in soil (below 1\%) [153] — soil characteristics that regularly occur in deeply weathered tropical soils. Otherwise, the probability that $\mathrm{Cd}$ accumulates in the soil in the long-term increases [156].

Against this background, only the existing limit value of $50 \mathrm{mg} \mathrm{Cd} / \mathrm{kg} \mathrm{P}_{2} \mathrm{O}_{5}$ according to the German DüMV could displace most mineral $P$ fertilizers from the market and thus indirectly promote organic/recycled P fertilizers. However, this potential steering effect is counteracted by the fact that the DüMV only applies to the marketing of fertilizers which are not declared as "EC-fertilizers" (§ 2 Para. 1 DüMV). The limit value of $80 \mathrm{mg} / \mathrm{kg} \mathrm{P}_{2} \mathrm{O}_{5}$ decided in Costa Rica in 2016, on the other hand, is to be regarded as comparatively high and therefore still permits the usage of most mineral P fertilizers. In Nicaragua, there is no steering effect with regard to the limited use of mineral $P$ fertilizers due to the lack of limit values. As a result, the use of mineral $P$ fertilizers has not yet been significantly restricted in any of the three countries by qualitative approval requirements.

In the context of the current amendment process of Regulation EC 2003/2003, setting an EU-wide limit for Cd in mineral fertilizers-after its failure in 2003 [157] —is again discussed within the Circular Economy Package [28]. The European Parliament supports the proposal to introduce a limit value for $\mathrm{Cd}$ of $60 \mathrm{mg} / \mathrm{kg} \mathrm{P}_{2} \mathrm{O}_{5}$ and to reduce it to $40 \mathrm{mg} / \mathrm{kg} \mathrm{P} \mathrm{P}_{2} \mathrm{O}_{5}$ after six years and to $20 \mathrm{mg} / \mathrm{kg} \mathrm{P}_{2} \mathrm{O}_{5}$ after 16 years [158]. Nonetheless, the long transition periods do not reflect the need for rapid change in the agricultural sector, which is unlikely to come of its own accord, as long as mineral P fertilizers continue to be available at reasonable prices. The EU-wide promotion of $\mathrm{P}$ fertilizers from secondary sources such as organic or recycled $\mathrm{P}$ fertilizers intended by setting limits for $\mathrm{Cd}$ must take place more quickly, especially in order to meet the international objectives in the area of climate and biodiversity protection. It remains to be seen whether the amended European Fertilizer Ordinance will finally set limits for $\mathrm{Cd}$ and what form this will ultimately take. 


\subsubsection{Applied Fertilizer Legislation}

With regard to the application of fertilizers, the provisions of the Fertilization Act (DüngG) [159] and the Fertilization Ordinance (DüV) [160] apply in Germany. They were comprehensively reformed in 2017, not least in order to avert conviction of Germany under the European Commission's infringement proceedings for excessive $\mathrm{N}$ inputs into surface and groundwater bodies. This is also reflected in the extended purpose of the Fertilizer Act, which now includes ensuring sustainable and resource-efficient handling of nutrients in agriculture and avoiding nutrient losses into the environment (§1 DüngG). According to $§ 3$ para. 2 DüngG, fertilization must be applied following Good Agricultural Practice. This is further specified in the DüV and comprises the application principles in $\S 3 \mathrm{DüV}$, in particular the location- and needs-based fertilization. The basis is the soil samples prescribed in $\S 4 \mathrm{DüV}$, whereby the available P-quantities must be determined at least every six years in accordance with $\S 4$ (4) No. 2 DüV. Following the amendment, Annex 4 of the DüV contains more precise specifications for determining the plant's nutrient requirements, although the specifications only apply to N. In principle, the new $\mathrm{DüV}$ focuses significantly more on $\mathrm{N}$ than on $\mathrm{P}$, which is reflected not only in the details for the plants requirements but also in the limitation of the absolute $\mathrm{N}$ input in accordance with $\S 6$ (4) DüV. A corresponding regulation for $\mathrm{P}$ is missing. Specifically, for $\mathrm{P}$ fertilization, the new DüV provides in $\S$ 3 para. 6 that $\mathrm{P}$ fertilization in areas with $>20 \mathrm{mg} \mathrm{P}_{2} \mathrm{O}_{5}$ per $100 \mathrm{~g}$ of soil may only be carried out up to the level of the expected phosphate removal. Appeals can only be made in individual cases or on the basis of the newly introduced country authorisation clause ( $\$ 13(2) \mathrm{s} .4$ No. 3 DüV). In fact, the new $\S 9$ para. 3 DüV halves the permitted average six-year P balances from $20 \mathrm{~kg} / \mathrm{ha} / \mathrm{a}$ to $10 \mathrm{~kg} / \mathrm{ha} / \mathrm{a}$ starting from 2023. Yet, $\mathrm{P}$ surpluses and thus potential P losses remain permissible. Overall, the new fertilizer law, with the obligation to apply P fertilizers in line with demand, the P limitation to highly supplied soils and the limitation of the maximum $\mathrm{P}$ balances as well as some application restrictions, certainly includes approaches for more sustainable P management, but does not make full use of its potential [132].

In Costa Rica and Nicaragua, a comparable applied fertilizer legislation does not exist. The handling or permitted quantity of $P$ fertilizer used as well as permissible nutrient surpluses in soils are not prescribed by law. Instead, there are general guidelines on Good Agricultural Practice (Buenas Prácticas Agrícolas, BPA). The BPA was supported in Central America from 2009 to 2011 under the Protocol on Land-Based Pollution of the Caribbean. This legally binding protocol was concluded on the basis of Art. 4 para. 3 and Art. 17 of the Cartagena Protocol [161] as an initiative of the United Nations Environment Programme [162]. In this context, instructions on BPA for various crops, the preferred use of organic fertilizers and integrated pest management have been developed [163-166]. The objective of the BPA is to achieve a more efficient use of fertilizers and pesticides in agriculture. In a reference project on banana cultivation on the Caribbean coast of Costa Rica, the use of mineral fertilizers fell by $25 \%$ [167] (p. 28), [168] (p. 3). The complete renunciation of mineral fertilizers and pesticides is not foreseen and there is therefore considerable scope for the application of BPA.

However, the concept of BPA is based on the principle of voluntary certification. In particular, domestic small and medium-sized producers are addressed by the BPA. Due to the lack of domestic sales markets and high certification costs, the application of BPA has not yet been fully established, neither in Costa Rica nor in Nicaragua. Even though the certification costs in Costa Rica can be partially covered by the "Recognition of Environmental Benefits" programme [169]—a type of investment subsidy [170] (p. 142)—only 252 farmers applied the BPA in 2016 [40] (p. 4). According to Costa Rica's National Development Plan for 2015-2018, the objective is to integrate a total of 1600 farms into the BPA [40] (p. 4). During the last survey of the BPA in Nicaragua in 2011, about 750 producers applied the BPA [171] (p. 5).

In addition, Law No. 765 [172] in Nicaragua explicitly pursues the goal of promoting agroecological and organic agriculture. In Costa Rica, Law No. 8591 [173] and its implementing regulation [174] to promote organic farming was enacted in 2007. Again, certification for organic agricultural products is only desirable for the producer if corresponding markets exist. This has not yet been sufficiently achieved 
within Nicaragua and Costa Rica. The total share of ecologically certified production is $0.4 \%$ in Costa Rica and $0.7 \%$ in Nicaragua [35] (p. 46). Approximately 28,000 farmers in Nicaragua work according to agricultural-ecological principles, some of them however without certification [175] (p. 5).

Overall, the problem is that binding national regulations for the utilization of fertilizers valid for all farmers do not exist, and also the requirements for BPA have not been incorporated into national legislation or been improved with regard to efficient and consistent use of $(\mathrm{P})$ fertilizers. In this respect, a governance gap exists in Costa Rica and Nicaragua [176]. In Costa Rica, Art. 19 of Law 7779 already provides the legal basis for the integration of binding regulations for the utilisation of fertilizers in the field of soil protection law. However, the lack of consistent implementation appeals to be a result of an ambition gap [177]. Riggs identifies an "ambition gap" [178] (p. 3) particularly with regard to the implementation of climate protection targets in accordance with the PA. This can also be applied to the missing establishment of national soil protection plans in Costa Rica, which would have to include rules for appropriate P fertilization practices (Art. 19 Law 7779) [129] and might also be applicable to the missing specification of soil protection legislation in Nicaragua.

Thus, from a comparative legal perspective, it can be stated that mineral $\mathrm{P}$ fertilizer use in agriculture remains either insufficiently regulated as in Germany or is not subject to any legally binding restrictions in Costa Rica or Nicaragua. In particular, Good Agricultural Practices-as it is understood and designed in each case-do not yet promote the closing of the P nutrient cycles and hence the protection of soils adequately; even though the German fertilizer law has recently been amended to improve nutrient efficiency. As a result, Good Agricultural Practice must be comprehensively reoriented in all countries to meet the future challenges with regard to sufficient food production as well as resource and environmental protection. However, increased and more intensive monitoring and enforcement problems [29] (p. 467) are likely to occur if strict and binding rules for Good Agricultural Practice are established. It may therefore also be necessary to create further, alternative legal instruments (see also Section 4).

\section{Discussion and Concluding Remarks}

Germany, Costa Rica and Nicaragua are each facing the challenge of overcoming dependence on imported mineral $\mathrm{P}$ extracted from mining and establishing sustainable agriculture with closed nutrient cycles, so that natural resources are protected in the long-term. A P-governance that consistently aims to reduce the amount of mineral $P$ fertilizers used and promotes alternative fertilizers, and therefore also considers protection of soil, water, biodiversity, and climate is appropriate. So far, legislation in all three countries has not yet found the right answers to the existing challenges, even though obligations in the area of environmental protection can be derived from internationally binding agreements as well as from fundamental rights. In all three countries, agriculture is still essentially dependent on the use of fossil fuels and mineral (P) fertilizers. In each case, a strong export orientation, with far-reaching separation of livestock farming and crop production is evident, while permitting negative environmental effects on soils, water, biodiversity and climate, which may ultimately lead to irreversible environmental damage [29] (pp. 450-459), [90].

In order to close the $\mathrm{P}$ fertilizer cycles in the future, a better understanding of the process of $\mathrm{P}$ is necessary. In general, measures to increase the availability of $\mathrm{P}$ in the soil for plants are increasingly being investigated. Microorganisms, mycorrhization and crop rotation play a decisive role in this context [179]. This applies equally to Central European and tropical soils. Organic fertilization, mixed cultivation and intercropping - principles which contribute to increase the plant availability of $\mathrm{P}$-have so far been most closely anchored in agroecological and organic agriculture. These practices are inadequately promoted. Legal initiatives in this regard have not achieved the desired results and are largely overshadowed by export-oriented agricultural policies. In non-European countries such as Costa Rica and Nicaragua, misguided subsidies under the CAP, which are insufficiently linked to environmental requirements or the utilisation of organic fertilizers within Europe, additionally 
increase the pressure to produce competitively $[180,181]$, and in cases of doubt with a high use of mineral (P) fertilizers.

Soil protection is also inadequate in each case. In Germany, partly contrary special laws in the fertilizer legislation prevent comprehensive soil protection. In Costa Rica the lack of implementation of existing soil protection and in Nicaragua the general, inadequately specified requirements for soil protection law do not show any relevance in practice. At the same time, the use of mineral $P$ fertilizers is largely uncontrolled or misguided in the individual countries. The respective product-related fertilizer legislation has already missed the possibility of restricting the use of mineral $P$ fertilizers and thus indirectly promoting organic or recycled P fertilizers; for instance, through strict limit values for heavy metals such as $\mathrm{Cd}$.

In addition, there are no control mechanisms which can consistently minimise the total quantity of mineral $\mathrm{P}$ used, and legislation in the individual states does not encourage any structural changes in agriculture. These should aim in particular at livestock farming practices that are optimally adapted to the site-specific conditions. In particular, it was shown that livestock production needs to be strongly minimized in total and at the same time much better distributed spatially than today [74]. In order to achieve this and to close P nutrient cycles in agriculture, efficiency and consistency (such as precision farming and $P$ recycling) and in particular frugality, i.e., more modest consumption patterns, have to be included in $\mathrm{P}$ governance. So far, also the recovery of $\mathrm{P}$ from sewage sludge prescribed in Germany by the amended AbfKlärV [145] as an important consistency strategy neither encourages any structural changes in agriculture nor stimulates frugality and can therefore be seen as only one step on the way to close the existing governance gap. In this context, the potential steering effect of command-and-control law in agricultural legislation must generally be questioned, since-also in Germany-a large number of individual processes in agriculture make corresponding implementation difficult. In addition, there are fundamental governance deficiencies in the regulatory approaches such as possible rebound and shifting effects [29] (pp. 408-412). Command-and-control and subsidy approaches with their focus on a special place, action, or product have the disadvantage that they tend to trigger unwanted shifting effects of environmental problems to other countries and where possible, to other sectors. Reducing fertilization e.g., in Germany, could lead to intensified farming practices elsewhere. This also makes it hard to primarily focus on new approaches that are only established on a domestic level (e.g., meat tax). Also, there are potential rebound effects if e.g., fertilizer use is improved in a specific area, while at the same time the overall global trend of increasing land use continues. Frugality and the general need for quantity control for various resource and sink problems might require economic rather than regulatory approaches as the main instrument, which does not necessarily exclude the need for additional regulatory requirements. A cross-sectoral and ambitious cap on the availability or pricing of fossil fuels, land use or livestock farming as a first legislative action would be conceivable [76], [29] (pp. 459-470). In this respect, there is still a long way to go towards sustainable agriculture. One of the many steps towards this is closing the P governance gap [176].

Author Contributions: J.S. wrote most of the paper; B.G. contributed the text regarding EU and German legislation; F.E. read, improved and supplemented the final manuscript and delivered the methodological and theoretical background of the analysis.

Funding: This research was funded by the Leibniz Association within the scope of the Leibniz ScienceCampus Phosphorus Research Rostock (www.sciencecampus-rostock.de) and the BonaRes-Project InnoSoilPhos (http:/ / www.innosoilphos.de/). The authors thank the Leibniz Association and the BMBF for long-term funding. Furthermore, we acknowledge financial support by Deutsche Forschungsgemeinschaft and University of Rostock within the funding programme Open Access Publishing.

Conflicts of Interest: The authors declare no conflicts of interest.

\section{References}

1. United Nations. Transforming Our World: The 2030 Agenda for Sustainable Development; United Nations: New York, NY, USA, 2015. 
2. U.S. Geological Survey. Mineral Commodity Summaries, January 2018; U.S. Geological Service: Reston, VA, USA, 2018.

3. FAOSTAT. Available online: http://www.fao.org/faostat/en/\#data/EF (accessed on 4 April 2018).

4. Kratz, S.; Schick, J.; Shwiekh, R.; Schnug, E. Abschätzung des Potentials erneuerbarer P-haltiger Rohstoffe in Deutschland zur Substitution rohphosphathaltiger Düngemittel. J. Kult. 2014, 66, 261-275. [CrossRef]

5. Bundesanstalt für Geowissenschaften und Rohstoffe (BGR). Phosphat, Rohstoffwirtschaftliche Steckbriefe, Juli 2014; BGR: Hannover, Germany, 2014.

6. De Ridder, M.; de Jong, S.; Polchar, J.; Lingemann, S. Risks and Opportunities in the Global Phosphate Rock Market: Robust Strategies in Times of Uncertainty; The Hague Centre for Strategic Studies (HCSS): The Hague, The Netherlands, 2012.

7. Leinweber, P.; Bathmann, U.; Buczko, U.; Douhaire, C.; Eichler-Löbermann, B.; Frossard, E.; Ekardt, F.; Jarvie, H.; Krämer, I.; Kabbe, C.; et al. Handling the phosphorus paradox in agriculture and natural ecosystems: Scarcity, necessity, and burden of P. Ambio 2018, 47, 3-19. [CrossRef] [PubMed]

8. Heckenmüller, M.; Narita, D.; Klepper, G. Global Availability of Phosphorus and Its Implication for Global Food Supply: An Economic Overview; Kiel Working Paper No. 1897; Kiel Institute for the World Economy: Kiel, Germany, 2014.

9. Cordell, D.; White, S. Clarifying the key issues of a vigorous debate about long-term phosphorus security. Sustainability 2011, 3, 2027-2049. [CrossRef]

10. Khabarov, N.; Obersteiner, M. Global Phosphorus Fertilizer Market and National Policies: A Case Study Revisiting the 2008 Price Peak. Front. Nutr. 2017, 14, 4-22. [CrossRef] [PubMed]

11. Ministerio de Economia, Industria y Comercio (MEIC). Estudio Preliminar Para Determinar la Posibilidad de Regular el Mercado de Fertilizantes en Costa Rica; MEIC: San José, Costa Rica, 2014.

12. Scholz, R.W.; Wellmer, F.W. Approaching a Dynamic View on the Availability of Mineral Resources: What May We Learn from the Case of Phosphorus? Glob. Environ. Chang. 2013, 23, 11-27. [CrossRef]

13. Ekardt, F.; Stubenrauch, J. Schadstoffanreicherungen in Böden als Governance-und Rechtsproblem-Das Beispiel Cadmium: Zugleich zu einigen Grundproblemen von Ordnungsrecht. In Jahrbuch des Umwelt-und Technikrechts 2013; Hebeler, T., Hendler, R., Proels, A., Reiff, P., Eds.; ESV: Trier, Germany, 2013; pp. 173-191, ISBN 978-3-503-15413-5.

14. Bayerische Landesanstalt für Landwirtschaft (LfL). 20 Jahre Boden-Dauerbeobachtung in Bayern, Teil 3: Entwicklung der Humusgehalte zwischen 1986 und 2007, 2nd ed.; LfL: Freising-Tüntenhausen, Germany, 2011.

15. Klimanek, E.M. Bedeutung der Ernte-und Wurzelrückstände landwirtschaftlich genutzter Pflanzenarten für die organische Substanz des Bodens. Arch. Agron. Soil Sci. 1997, 41, 485-511. [CrossRef]

16. European Environment Agency (EEA). European Waters-Assessment and Pressures; EEA: Copenhagen, Denmark, 2012.

17. Sharpley, A.N.; Bergström, L.; Aronsson, H.; Bechmann, M.; Bolster, C.H.; Börling, K.; Djodic, F.; Jarvie, H.P.; Schoumans, O.F.; Stamm, C.; et al. Future agriculture with minimized P losses to waters: Research needs and directions. Ambio 2015, 44, 163-179. [CrossRef] [PubMed]

18. Withers, P.J.A.; Jarvie, H.P. Delivery and cycling of phosphorus in rivers: A review. Sci. Total Environ. 2008, 400, 379-395. [CrossRef] [PubMed]

19. Whitehead, P.G.; Wilby, R.L.; Battarbee, R.W.; Kernan, M.; Wade, A.J. A review of the potential impacts of climate change on surface water quality. Hydrol. Sci. J. 2009, 54, 101-121. [CrossRef]

20. Hägg, H.E.; Lyon, S.W.; Wällstedt, T.; Mörth, C.M.; Claremar, B.; Humborg, C. Future nutrient load scenarios for the Baltic Sea due to climate and lifestyle changes. Ambio 2013, 43, 337-351. [CrossRef] [PubMed]

21. Clara, L.; Fatma, R.; Viridiana, A.; Liesl, M. Soil Organic Carbon: The Hidden Potential; Food and Agriculture Organisation (FAO): Rome, Italy, 2017.

22. Cai, W.; Borlace, S.; Lengaigne, M.; van Rensch, P.; Collins, M.; Vecchi, G.; Timmermann, A.; Santoso, A.; McPhaden, M.J.; Wu, L.; et al. Increasing frequency of extreme El Niño events due to greenhouse warming. Nat. Clim. Chang. 2014, 4, 111-116. [CrossRef]

23. Coumou, D.; Kornhuber, K.; Lehmann, J.; Pethoukhov, V. Weakened Flow, Persistent Circulation, and Prolonged Weather Extremes in Boreal Summer. In Climate Extremes: Patterns and Mechanisms; Wang, S., Yoon, J.H., Funk, C.C., Gilies, R.R., Eds.; American Geophysical Union: Washington, DC, USA, 2017; pp. 61-75, ISBN 9781119068020. 
24. Mann, M.E.; Rahmstorf, S.; Kornhuber, K.; Steinman, B.A.; Miller, S.K.; Coumou, D. Influence of Anthropogenic Climate Change on Planetary Wave Resonance and Extreme Weather Events. Sci. Rep. 2017, 7, 45242. [CrossRef] [PubMed]

25. Rockström, J.; Gaffney, O.; Rogelj, J.; Meinshausen, M.; Nakicenovic, N.; Schellnhuber, H.J.A. A roadmap for rapid decarbonization. Science 2017, 355, 1269-1271. [CrossRef] [PubMed]

26. Schaeffer, M.; Rogelj, J.; Roming, N.; Sferra, F.; Hare, B.; Serdeczny, O. Feasibility of Limiting Warming to 1.5 and $2{ }^{\circ} \mathrm{C}$; Climate Analytics gGmbH: Berlin, Germany, 2015.

27. Intergovernmental Panel on Climate Change (IPCC). Climate Change 2014: Synthesis Report; IPCC: Geneva, Switzerland, 2014.

28. European Commission. Circular Economy Package. Proposal for a Regulation of the European Parliament and of the Council Laying down Rules on the Making Available on the Market of CE Marked Fertilizing Products and Amending Regulations (EC) No. 1069/2009 and (EC) No. 1107/2009; European Commission: Brussels, Belgium, 2016.

29. Ekardt, F. Theorie der Nachhaltigkeit: Ethische, Rechtliche, Politische und Transformative Zugänge-Am Beispiel von Klimawandel, Ressourcenknappheit und Welthandel, 2nd ed.; NOMOS: Baden-Baden, Germany, 2016; ISBN 9783832960322.

30. Rösler, H. Rechtsvergleichung als Erkenntnisinstrument in Wissenschaft, Praxis und Ausbildung. Jurist. Schul. 1999, 12, 1186-1191.

31. Coendet, T. Rechtsvergleichende Argumentation: Phänomenologie der Veränderungen im Rechtlichen Diskurs; Mohr-Siebeck: Tübingen, Germany, 2012; ISBN 978-3-16-152311-3.

32. Meuser, M.; Nagel, U. ExpertInneninterviews-Vielfach erprobt, wenig bedacht. Ein Beitrag zur qualitativen Methodendiskussion. In Das Experteninterview. Theorie, Methode, Anwendung, 2nd ed.; Bogner, A., Littig, B., Menz, W., Eds.; EV Verlag: Wiesbaden, Germany, 2005; pp. 71-94, ISBN 3-531-14447-2.

33. Statistische Ämter des Bundes und der Länder. Agrarstrukturen in Deutschland. Einheit und Vielfalt. Regionale Ergebnisse der Landwirtschaftszählung 2010; Statistische Ämter des Bundes und der Länder: Stuttgart, Germany, 2011.

34. Reichert, T. Der große Strukturwandel. In Fleischatlas. Daten und Fakten über Tiere als Nahrungsmittel. Deutschland Regional; Heinrich-Böll-Stiftung; BUND: Berlin, Germany, 2016; pp. 8-9, ISBN 9781370142255.

35. Forschungsinstitut für biologischen Landbau (FIBL), International Federation of Organic Agriculture Movements (IFOAM). The World of Organic Agriculture. Statistics \& Emerging Trends 2017; FIBL, IFOAM: Frick, Switzerland, 2017.

36. Destatis Statistisches Bundesamt. Available online: https://www.destatis.de/DE/ZahlenFakten/Wirtschaft sbereiche/LandForstwirtschaftFischerei/LandwirtschaftlicheBetriebe/LandwirtschaftlicheBetriebe.html (accessed on 3 April 2018).

37. Rodrigo, A. Welthandel ist Flächenhandel-Und ungerechter Verbrauch. In Bodenatlas. Daten und Fakten über Acker, Land und Erde, 4th ed.; Chemnitz, C., Weigelt, J., Eds.; Heinrich-Böll-Stiftung: Berlin, Germany, 2015; pp. 24-25. Available online: https://www.boell.de/de/bodenatlas (accessed on 3 April 2018).

38. Deutsche Agrarforschungsallianz (DAFA). Fachforum Grünland. Grünland Innovativ Nutzen und Ressourcen Schützen; DAFA: Braunschweig, Germany, 2016.

39. Instituto Nacional de Estadística y Censos (INEC). VI Censo Nacional Agropecuario. Resultados Generales; INEC: San José, Costa Rica, 2015.

40. Secretaría Ejecutiva de Planificación Sectorial Agropecuaria (SEPSA). Sector Agropecuario y Rural: Informe de Verificación de Metas PND 2016; SEPSA: San José, Costa Rica, 2017.

41. Camino Velozo, R.; Villalobos, R.; Morales Aymerich, J.P. Costa Rica Case Study: Prepared for FAO as Part of the State of the World's Forests 2016; FAO: San José, Costa Rica, 2016. Available online: http:/ /www.fao.org/3/ac0180e.pdf (accessed on 4 April 2018).

42. Bach, O. Estado de la Nación en Desarrollo Humano Sostenible, Agricultura y Sostenibilidad; San José, Costa Rica, 2013. Available online: https:/ / estadonacion.or.cr/files/biblioteca_virtual/020/ambiente/Bach_Agricult ura.pdf (accessed on 4 April 2018).

43. Instituto Nacional de Estadística y Censos (INEC). Estado de la Nación; INEC: San José, Costa Rica, 2015.

44. FAOSTAT. Available online: http://www.fao.org/faostat/en/?\#data/QC (accessed on 3 April 2018). 
45. Echeverría-Sáenz, S.; Mena, F.; Pinnock, M.; Ruepert, C.; Solano, K.; de la Cruz, E.; Campos, B.; Sánchez-Avila, J.; Lacorte, S.; Barata, C. Environmental hazards of pesticides from pinapple crop production in the Río Jímenez watershed (Caribbean Coast, Costa Rica). Sci. Total Environ. 2012, 440, 106-114. [CrossRef] [PubMed]

46. Rudel, T.K.; Defries, R.; Asner, G.P.; Laurance, W.F. Changing drivers of deforestation and new opportunities for conservation. Conserv. Biol. 2009, 23, 1396-1405. [CrossRef] [PubMed]

47. Harvey, C.A.; Alpízar, F.; Chacón, M.; Madrigal, R. Assessing Linkages between Agriculture and Biodiversity in Central America: Historical Overview and Future Perspectives; The Nature Conservancy: Airlington County, VA, USA, 2005; ISBN 9968-9557-1-X.

48. FAOSTAT. Available online: http://www.fao.org/faostat/en/\#data/RP (accessed on 4 April 2018).

49. Bertsch, H.F. Problemas de Fertilidad de Suelos de Costa Rica. In Memoria. Fertilidad de Suelos y Manejo de la Nutrición de Cultivos en Costa Rica; Melèndez, G., Molina, E., Eds.; CIA/UCR: San José, Costa Rica, 2001; pp. 1-10, ISBN 9789977917559.

50. Vitousek, P.M.; Denslow, J.S. Nitrogen and Phosphorus Availability in Treefall Gaps of a lowland tropical rainforest. J. Ecol. 1986, 74, 1167-1178. [CrossRef]

51. The World Bank. Available online: https: / / data.worldbank.org/indicator/SL.AGR.EMPL.ZS?end=2010\&1 ocations=NI\&start=1990\&view=chart (accessed on 4 April 2018).

52. CEPALSTAT Databases and Statistical Publications. Available online: http:/ / estadisticas.cepal.org/cepalstat /Perfil_Nacional_Economico.html?pais=NIC\&idioma=english (accessed on 4 April 2018).

53. Banco Central de Nicaragua. Available online: http://www.bcn.gob.ni/estadisticas/sector_externo/comer cio_exterior/exportaciones/4.pdf (accessed on 4 April 2018).

54. Banco Central de Nicaragua. Available online: http://www.bcn.gob.ni/divulgacion_prensa/notas/2017/n oticia.php?nota=522 (accessed on 4 April 2018).

55. Piccioni, N.B.; Barea, A.G. Agriculture in Nicaragua: Performance, Challenges, and Options; World Bank Group: Washington, DC, USA, 2015. Available online: http:/ / documents.worldbank.org/curated/en/53213148544 0242670 / Agriculture-in-Nicaragua-performance-challenges-and-options (accessed on 4 April 2018).

56. Instituto Nacional de Información de Desarrollo (INIDE), Ministerio Agropecuario y Forestal (MAGFOR). IV Censo Nacional Agropecuario, Informe Final 2012; INDIE, MAGFOR: Managua, Nicaragua, 2012.

57. Baumeister, E. Concentración de las Tierras y Seguridad Alimentaria en Centroamérica; International Land Coalition, Norwegian Development Fund: Rome, Italy, 2013; pp. 1-88, ISBN 978-92-95093-85-0.

58. Unión Nacional de Agricultores y Ganaderos de Nicaragua (UNAG). Available online: http://unag.org.ni/ ?p=2137\#more-2137 (accessed on 4 April 2018).

59. Productores Prudentes con Entrada del Invierno. Available online: http://www.elnuevodiario.com.ni/nac ionales/360524-productores-prudentes-entrada-invierno/ (accessed on 4 April 2018).

60. Informationsbüro Nicaragua e.V. Rum oder Gemüse? Landwirtschaft in Kuba und Nicaragua Zwischen Ernährungssouveränität, Kooperativen und Weltmarkt; Informationsbüro Nicaragua e.V.: Wuppertal, Germany, 2015; pp. 1-150, ISBN 987-3-9814936-3-4.

61. Oberfrank, M. Agrarfront im Regenwald Grenzziehungen und Grenzüberschreitungen in Nicaraguas Biosphärenreservat BOSAWAS; LIT Verlag: Münster, Germany, 2005; pp. 1-258, ISBN 3825885208.

62. Centro Humboldt, Alianza Nicaragüense Ante el Cambio Climàtico (ANACC). Agenda Ambiental Para el Desarrollo Sostenible, Nicaragua 2020; Centro Humboldt, ANACC: Managua, Nicaragua, 2016.

63. Bermúdez, M.; Flores, S.; Romero, M.; Bastiaensen, J.; Merlet, P.; Huybrechs, F.; van Hecken, G.; Ramirez, J. Is It Possible to Finance Livestock in a Sustainable Manner in Nicaragua's Agricultural Frontier; Nitlapan-Universidad Centroamericana, Appui au Développement Autonome (ADA): Luxembourg, Belgium, 2016.

64. Fassbender, H.W.; Bornemisza, E. Química de Suelos con Énfasis en Suelos de América Latina, 3rd ed.; Inter-American Institute for Cooperation on Agriculture (IICA): San José, Costa Rica, 1994; pp. 1-420, ISBN 9290391243.

65. United Nations. Convention on Biological Diversity; United Nations: New York, NY, USA, 1992.

66. United Nations. International Convention to Combat Desertification in Countries Experiencing Serious Drought and/or Desertification, Particularly in Africa; United Nations: New York, NY, USA, 1994.

67. United Nations. Adoption of the Paris Agreement; United Nations: New York, NY, USA, 2015. 
68. Ekardt, F.; Wieding, J. Rechtlicher Aussagegehalt des Paris-Abkommens; ZfU Special Edition; ZfU: Berlin, Germany, 2016; pp. 36-57.

69. Withers, P.; Neal, C.; Jarvie, H.P.; Doody, D.G. Agriculture and eutrophication: Where do we go from here? Sustainability 2014, 6, 5853-5875. [CrossRef]

70. Dudgeon, D.; Arthington, A.H.; Gessner, M.Q.; Kawabata, Z.; Knowler, D.J.; Lévêque, C.; Naiman, R.J.; Prieur-Richard, A.H.; Soto, D.; Stiassny, M.L.J. Freshwater biodiversity: Importance, threats, status and conservation challenges. Biol. Rev. 2006, 8, 163-182. [CrossRef] [PubMed]

71. Giller, K.E.; Beare, M.H.; Lavelle, P.; Izac, A.-M.N.; Swift, M.J. Agricultural intensification, soil biodiversity and agroecosystem function. Appl. Soil Ecol. 1997, 6, 3-16. [CrossRef]

72. Hartmann, M.; Frey, B.; Mayer, J.; Mäder, P.; Widmer, F. Distinct soil microbial diversity under long-term organic and conventional farming. Multidiscip. J. Microb. Ecol. 2015, 9, 1177-1194. [CrossRef] [PubMed]

73. Machovina, B.; Feeley, K.J.; Ripple, W.J. Biodiversity conservation: The key is reducing meat consumption. Sci. Total Environ. 2015, 536, 419-431. [CrossRef] [PubMed]

74. Nesme, T.; Withers, P.J.A. Sustainable strategies towards a phosphorus circular economy. Nutr. Cycl. Agroecosyst. 2016, 104, 259-264. [CrossRef]

75. Ekardt, F.; Zorn, A.; Wieding, J. In Zehn Jahren Nullemissionen? Widersprüche im Paris-Abkommen und Ihre Auflösung. Zugleich zu Vorsorgeprinzip und Überschätzten Klimaszenarien; Momentum Quarterly: Steyr, Austria, 2018; in press.

76. Ekardt, F.; Wieding, J.; Garske, B.; Stubenrauch, J. Landnutzungs-und düngungsbezogener Klimaschutz in europa- und völkerrechtlicher Perspektive. ZUR 2018, 3, 143-154.

77. Ekardt, F.; Garske, B.; Stubenrauch, J.; Wieding, J. Legal Instruments for Phosphorus Supply Security. J. Environ. Plan. Law 2015, 12, 261-343. [CrossRef]

78. Sachverständigenrat für Umweltfragen (SRU). Stickstoff: Lösungsstrategien für ein Drängendes Umweltproblem, Sondergutachten; SRU: Berlin, Germany, 2015; pp. 1-564, ISBN 978-3-503-16300-7.

79. Gellings, C.W.; Parmenter, K.E. Energy Efficiency in fertilizer production and use. In Efficient Use and Conservation of Energy, 2nd ed.; Gellings, C.W., Parmenter, K.E., Eds.; Eolss Publishers: Oxford, UK, 2004.

80. Statistisches Bundesamt (Destatis). Produzierendes Gewerbe. In Düngemittelversorgung; Destatis: Wiesbaden, Germany, 2017.

81. MC.Michael, A.J.; Powles, J.W.; Butler, C.D.; Uauy, R. Food, livestock production, energy, climate change, and health. Lancet 2007, 370, 1253-1263. [CrossRef]

82. Steinfeld, H.; Gerber, P.; Wassenaar, T.; Castel, V.; Rosales, M.; de Haan, C. Livestocks Long Shadow: Environmental Issues and Options; Food and Agriculture Organisation (FAO): Rome, Italy, 2006; ISBN 978-92-5-105571-7.

83. Raschka, A.; Carus, M. Stoffliche Nutzung von Biomasse Basisdaten für Deutschland, Europa und Die Welt; Nova Institut: Hürth, Germany, 2012.

84. International Fertilizer Association (IFA). Fertilizer Outlook 2017-2021; IFA: Marrakech, Morocco, 2017.

85. Bodirsky, B.; Popp, A.; Weindl, I.; Dietrich, J.P.; Rolinski, S.; Scheiffele, L.; Schmitz, C.; Lotze-Campen, H. N2O Emissions from the Global Agricultural Nitrogen Cycle-Current State and Future Scenarios. Biogeosciences 2012, 9, 4169-4197. [CrossRef]

86. International Assessment of Agricultural Knowledge, Science and Technology for Development (IAASTD). Agriculture at a Crossroads, Global Report; McIntyre, B.D., Herren, H.R., Wakhungu, J., Watson, R.T., Eds.; IAASTD: Washington, DC, USA, 2009.

87. Yanfang, X.; Haiyong, X.; Peter, C.; Zheng, Z.; Long, L.; Caixian, T. Crop acquisition of phosphorus, iron and zinc from soil in cereal/legume intercropping systems: A critical review. Ann. Bot. 2016, 117, 363-377. [CrossRef]

88. Lemaire, G.; Franzluebbers, A.; de Faccio Carvalho, P.C.; Dedieu, B. Integrated crop-livestock systems: Strategies to achieve synergy between agricultural production and environmental quality. Agric. Ecosyst. Environ. 2014, 190, 4-8. [CrossRef]

89. United Nations Convention to Combat Desertification (UNCCD). Global Land Outlook, 1st ed.; UNCCD: Bonn, Germany, 2017.

90. Escribiano, A. Organic Livestock Farming-Challenges, Perspectives, and Strategies to Increase Its Contribution to the Agrifood System's Sustainability_A Review. IntechOpen 2016, 229-260. [CrossRef] 
91. Steffen, W.; Richardson, K.; Rockström, J.; Cornell, S.; Fetzer, I.; Bennett, E.M.; Biggs, R.; Carpenter, S.R.; de Vries, W.; de Wit, C.; et al. Planetary boundaries: Guiding human development on a changing planet. Science 2015, 347, 1259855. [CrossRef] [PubMed]

92. Susnjar, D. Proportionality, Fundamental Rights, and Balance of Powers; Brill Academic Pub: Leiden, The Netherlands, 2010; pp. 1-389, ISBN 9789004182868.

93. Calliess, C. Rechtsstaat und Umweltstaat, Zugleich ein Beitrag zur Grundrechtsdogmatik im Rahmen Mehrpoliger Verfassung; Mohr Siebeck: Tübingen, Germany, 2001; pp. 1-685, ISBN 978-3-16-147578-8.

94. Koch, T. Der Grundrechtsschutz des Drittbetroffenen; Mohr Siebeck: Tübingen, Germany, 2000; pp. 1-528, ISBN 978-3-16-147444-6.

95. Hoppe, W.; Beckmann, M.; Kauch, P. Umweltrecht, 3rd ed.; Beck: München, Germany, 2000; pp. 1-934, ISBN 1-978-3-406-40448-1.

96. Rehbinder, E. Ziele, Grundsätze, Instrumente. In Grundzüge des Umweltrechts, 4rd ed.; Hansmann, D., Sellner, K., Eds.; EVS: Saarbrücken, Germany, 2012; pp. 1-1258, ISBN 978-3-503-14106-7.

97. Gobierno de Costa Rica, Ministerio de Planificación Nacional y Política Económica (MIDEPLAN). Plan Nacional de Desarrollo 2015-2018. Alberto Cañas Escalante; MIDEPLAN: San José, Costa Rica, 2014; pp. 1-560, ISBN 978-9977-73-084-4.

98. Altieri, M.A.; Toledo, V.M. The agroecological revolution in Latin America: Rescuing nature, ensuring food sovereignty and empowering peasants. J. Peasant Stud. 2011, 38, 578-612. [CrossRef]

99. Partial Constitutional Reform. Ley de Reforma Parcial a la Constitución Política de la Republica Nicaragua; Law No 854; Gazette: Managua, Nicaragua, 2014.

100. Exodo. Available online: http:/ / www.exodo.org/declaracion-universal-de-bien-2/ (accessed on 9 April 2018).

101. El Nuevo Diario. Available online: https://www.elnuevodiario.com.ni/opinion/70581-bien-comun-tierra -humanidad/ (accessed on 9 April 2018).

102. Ekardt, F. Sustainability: Transformation, Governance, Ethics, Law; Springer: Dordrecht, The Netherlands, 2018.

103. European Commission. Council Directive of 12 December 1991 Concerning the Protection of Waters against Pollution Caused by Nitrates from Agricultural Sources; JO No L 275/1; European Commission: Brussels, Belgium, 1991.

104. European Commission. Report from the Commission to the Council and the European Parliament on the Implementation of Council Directive 91/676/EEC Concerning the Protection of Waters against Pollution Caused by Nitrates from Agricultural Sources Based on Member State Reports for the Period 2008-2011; European Commission: Brussels, Belgium, 2013; pp. 1-11.

105. European Commission. Directive 2000/60/EG of the European Parliament and of the Council of 23 October 2000 Establishing a Framework for Community Action in the Field of Water Policy; JO No L 327/1; European Commission: Brussels, Belgium, 2000.

106. European Court of Auditors. Is Cross Compliance an Effective Policy? Special Issue Report No 8/2008; European Court of Auditors: Luxembourg, 2008.

107. European Commission. Regulation (EU) No 1306/2013 of the European Parliament and of the Council of 17 December 2013 on the Financing, Management and Monitoring of the Common Agricultural Policy and Repealing Council Regulations (EEC) No 352/78, (EC) No 165/94, (EC) No 2799/98, (EC) No 814/2000, (EC) No 1290/2005 and (EC) No 485/2008; JO No L 347/608; European Commission: Brussels, Belgium, 2013.

108. Möckel, S. Political and legal objectives for precautionary soil conservation in Germany. NuL 2015, 11, 497-502. [CrossRef]

109. European Commission. Communication from the Commission to the European Parliament, the Council, the European Economic and Social Committee and the Committee of the Regions. Consultative Communication on the Sustainable Use of Phosphorus; European Commission: Brussels, Belgium, 2013; pp. 1-19.

110. European Court of Auditors. Integration of EU Water Policy Objectives with the CAP: A Partial Succes; Special Report; European Court of Auditors: Luxembourg, 2014; pp. 1-68, ISBN 978-92-872-0028-0.

111. Von Cramon-Taubadel, S.; Heinemann, F. The EU's Agricultural Policy. Why Reform is Overdue. Policy Brief; Bertelsmann Stiftung: Gütersloh, Germany, 2017.

112. Pe'er, G.; Dicks, L.V.; Visconti, P.; Arlettaz, R.; Báldi, A.; Benton, T.G.; Collins, S.; Dieterich, M.; Gregory, R.D.; Hartig, F.; et al. EU agricultural reform fails on biodiversity. Science 2014, 344, 1090-1092. [CrossRef] [PubMed] 
113. European Commission. Regulation (EU) No 1307/2013 of the European Parliament and of the Council of 17 December 2013 Establishing Rules for Direct Payments to Farmers under Support Schemes within the Framework of the Common Agricultural Policy and Repealing Council Regulation (EC) No 637/2008 and Council Regulation (EC) No 73/2009; JO No L 347/608; European Commission: Brussels, Belgium, 2013.

114. European Commission. Regulation (EU) No 1305/2013 of the European Parliament and of the Council of 17 December 2013 on Support for Rural Development by the European Agricultural Fund for Rural Development (EAFRD) and Repealing Council Regulation (EC) No 1698/2005; JO No L 347/487; European Commission: Brussels, Belgium, 2013.

115. Pe'er, G.; Lakner, S.; Müller, R.; Passoni, G.; Bontzorlos, V.; Clough, D.; Moreira, F.; Azam, C.; Berger, J.; Bezak, P.; et al. Is the CAP Fit for Purpose? An Evidence Based Fitness-Check Assessment; German Centre for Integrative Biodiversity Research (iDiv) Halle-Jena-Leipzig: Leipzig, Germany, 2017.

116. Garske, B.; Hoffmann, K. Die Gemeinsame Agrarpolitik nach der Reform 2013: Endlich Nachhaltig? Tietje, C.: Halle, Germany, 2016; pp. 1-95, ISBN 978-3-86829-831-4.

117. Federal Law Gazette I. Federal Nature Conservation Act (Gesetz über Naturschutz und Landschaftspflege); Federal Law Gazette I: Berlin, Germany, 2009; p. 2542.

118. Möckel, S.; Köck, W.; Rutz, C.; Schramek, J. Rechtliche und Andere Instrumente für Vermehrten Umweltschutz in der Landwirtschaft; Umweltbundesamt (UBA): Dessau-Roßlau, Germany, 2014. Available online: https:/ / www.umweltbundesamt.de/publikationen/rechtliche-andere-instrumente-fuer-vermeh rtenUBA-Texte (accessed on 9 April 2018).

119. Federal Law Gazette I. Federal Water Act (Wasserhaushaltsgesetz); Federal Law Gazette I: Berlin, Germany, 2009; p. 2585.

120. Federal Law Gazette I. Federal Immission Control Act (Bundes-Immissionsschutzgesetz); Federal Law Gazette I: Berlin, Germany, 2013; p. 1274.

121. European Commission. Directive (EU) 2016/2284 of the European Parliament and of the Council of 14 December 2016 on the Reduction of National Emissions of Certain Atmospheric Pollutants, Amending Directive 2003/35/EC and Repealing Directive 2001/81/EC; JO No L 344/1; European Commission: Brussels, Belgium, 2016.

122. European Commission. Directive 2008/50/EC of the European Parliament and of the Council of 21 May 2008 on Ambient Air Quality and Cleaner Air for Europe; JO No L 152/1; European Commission: Brussels, Belgium, 2008.

123. Federal Law Gazette I. Federal Soil Conservation Act (Gesetz zum Schutz vor Schädlichen Bodenveränderungen und zur Sanierung von Altlasten); Federal Law Gazette I: Berlin, Germany, 1998; p. 502.

124. Proposal for a Directive of the European Parliament and of the Council Establishing a Framework for the Protection of Soil and Amending Directive 2004/35/EC/*COM/2006/0232 final-COD 2006/0086*/. Available online: https:/ / eur-lex.europa.eu/legal-content/EN/TXT/HTML/?uri=CELEX:52006PC0232\& from=EN (accessed on 24 May 2018).

125. Eu2017ee. Available online: https://www.eu2017.ee/de/neues/pressemitteilungen/minister-fuer-angele genheiten-des-laendlichen-raums-tarmo-tamm-bruessel (accessed on 9 April 2018).

126. Agriculture and Fisheries Council. Available online: http://www.consilium.europa.eu/en/meetings/agri fish/2017/11/06/ (accessed on 9 April 2018).

127. Gazette. Basic Act on the Environment No 7554 (Ley Orgánica del Ambiente); No 215; Gazette: San José, Costa Rica, 1995.

128. Gazette. Implementing Ordinance on Environmental Impact Assessment No 31849-MINAE-S-MOPT-MAG-MEIC (Reglamento General Sobre los Procedimientos de Evaluación de Impacto Ambiental); No 125; Gazette: San José, Costa Rica, 2004.

129. Gazette. Soil Conservation Act No 7779 (Uso, Manejo y Conservación de Suelos); No 97; Gazette: San José, Costa Rica, 1998.

130. Perfecto, I.; Vandermeer, J. The agroecological matrix as alternative to the landsparing/agriculture intensification model. Proc. Natl. Acad. Sci. USA 2010, 13, 5786-5791. [CrossRef] [PubMed]

131. Babin, N. The Coffee Crisis, Fair Trade, and Agroecological Transformation: Impacts on Land Use Change in Costa Rica. Agroecol. Sustain. Food Syst. 2015, 39, 99-129. [CrossRef]

132. Garske, B.; Douhaire, C.; Ekardt, F. Ordnungsrechtliche Instrumente der Phosphor-Governance. NuR 2018, 40, 73-81. [CrossRef]

133. Astorga Gattgens, A.; University of Costa Rica, San José, Costa Rica. Personal communication, 2016. 
134. Gazette. Basic Act on the Environment and Natural Resources No 217 (Ley General del Medio Ambiente y los Recursos Naturales); No. 105; Gazette: Managua, Nicaragua, 1996.

135. Gazette. Decree No 91/01 Regulation of the National Environment Fund (Reglamento del Fondo Nacional del Ambiente); No 195; Gazette: Managua, Nicaragua, 2001.

136. Gazette. National Forest Act No 462 (Ley de Conservación, Fomento y Desarrollo Sostenible del Sector Forestal); No 168; Gazette: Managua, Nicaragua, 2003.

137. Gazette. National Water Portection Act No 620 (Ley General de Aguas Nacionales); No 169; Gazette: Managua, Nicaragua, 2007.

138. Glaesner, N.; Helmig, K.; de Vries, W. Do Current European Policies Prevent Soil Threats and Support Soil Functions? Sustainability 2014, 6, 9538-9563. [CrossRef]

139. European Commission. Council Directive 85/337/EEC of 27 June 1985 on the Assessment of the Effects of Certain Public and Private Projects on the Environment; JO No L 175/40; European Commission: Brussels, Belgium, 1985.

140. Rodgers, C. Environmental governance and land use policy in tension? Applying environment impact assessment to tensive agriculture. In Research Handbook on Agriculture Law; McMahon, J.A., Cardwell, M.N., Eds.; Edward Elgar Publishing: Celtenham, UK, 2015; pp. 150-169, ISBN 978-1-78195462-1.

141. Gazette. Decree on Environmental Impact Assessment No 45-94 (Reglamento de Permiso y Evaluación de Impacto Ambiental); No 203; Gazette: Managua, Nicaragua, 1994.

142. Gazette. Decree on the Actualisation of the Environmental Impact Assessment No. 15-2017 (Actualización del Sistema de Evaluación Ambiental); No 163; Gazette: Managua, Nicaragua, 2017.

143. Federal Law Gazette I. Fertilizer Ordinance (Düngemittelverordnung); Federal Law Gazette I: Berlin, Germany, 2012; p. 2482.

144. European Commission. Regulation (EC) No 2003/2003 of the European Parliament and of the Council of 13 October 2003 Relating to Fertilizers; JO No L 304/1; European Commission: Brussels, Belgium, 2003.

145. Federal Law Gazette I. Sewage Sludge Ordinance (Klärschlammverordnung); Federal Law Gazette I: Berlin, Germany, 2017; p. 3465.

146. Federal Law Gazette I. Bio-Waste Ordinance (Bioabfallverordnung); Federal Law Gazette I: Berlin, Germany, 2013; p. 658.

147. Kominko, H.; Gorazda, K.; Wzorek, Z.; Wojtas, K. Sustainable Management of Sewage Sludge for the Production of Organo-Mineral Fertilizers. Waste Biomass Valoriz. 2017, 1-10. [CrossRef]

148. Gazette. Plant Protection Act No 7664 (Ley de Protección Fitosanitaria); No 83; Gazette: San José, Costa Rica, 1997.

149. Gazette. Basic Law on Animal and Plant Health No 291 (Ley Básica de Salud Animal y Sanidad Vegetal); No 136; Gazette: Managua, Nicaragua, 1998.

150. Central American Technical Regulation No 65.05.54:09 (RTCA 65.05.54:09 Fertilizantes y Enmiendas de uso Agrícola. Requisitos para el Registro). 5 January 2014. Available online: https:/ / members.wto.org/crnattac hments/2009/sps/CRI/09_1825_00_s.pdf (accessed on 10 April 2018).

151. Kratz, S.; Schnug, E. Schwermetalle in P-Düngern. In Recent Advances in Agricultural Chemistry; Haneklaus, S., Rietz, R.-M., Rogasik, J., Eds.; Forschungsanstalt für Landwirtschaft Braunschweig-Völkenrode: Braunschweig, Germany, 2005; pp. 37-45, ISBN 3-933140-92-7.

152. Gazette. Costa Rican Technical Regulation No 485:2016, (RTCR 485:2016 Sustancias Quimicas, Fertilizantes y Enmiendas Para uso Agrícola, Tolerancias y Límites Permitidos para la Concentración de los Elementos Contaminantes); No 241; Gazette: San José, Costa Rica, 2016.

153. Kördel, W.; Herrchen, M.; Müller, J.; Kratz, S.; Fleckenstein, J.; Schnug, E.; Saring, T.; Haamann, H.; Reinhold, J. Begrenzung von Schadstoffeinträgen bei Bewirtschaftungsmaßnahmen in der Landwirtschaft bei Düngung und Abfallverwertung; Umweltbundesamt (UBA): Dessau-Roßlau, Germany, 2007.

154. Dittrich, B.; Klose, R. Schwermetalle in Düngemitteln. Bestimmung und Bewertung von Schwermetallen in Düngemitteln, Bodenhilfsstoffen und Kultursubstraten; Sächsische Landesanstalt für Landwirtschaft: Dresden, Germany, 2008.

155. Kratz, S.; Schick, J.; Schnug, E. Trace Elements in rock phosphates and P containing mineral and organo mineral fertilizers sold in Germany. Sci. Total Environ. 2015, 542, 1013-1019. [CrossRef] [PubMed]

156. Stubenrauch, J. Schleichende Schadstoffanreicherung in Böden und Rechtswirkungsanalyse am Beispiel des Schwermetalls Cadmium. Diploma Thesis, University of Leipzig, Leipzig, Germany, 2013.

157. Cadmium in Fertilizers. Available online: https://ec.europa.eu/growth/content/cadmium-fertilizers_en (accessed on 10 April 2018). 
158. European Parliament. Available online: http://www.europarl.europa.eu/sides/getDoc.do?pubRef=- / /EP / /TEXT+TA+P8-TA-2018-0009+0+DOC+XML+V0/ /EN (accessed on 10 April 2018).

159. Federal Law Gazette I. Fertilization Act (Düngegesetz); Federal Law Gazette I: Berlin, Germany, 2009; p. 54.

160. Federal Law Gazette I. Fertilization Ordinance (Düngeverordnung); Federal Law Gazette I: Berlin, Germany, 2007; p. 1305.

161. United Nations. Protocol Concerning Pollution from Land-Based Sources and Activities to the Convention for the Protection and Development of the Marine Environment of the Wider Caribbean Region; United Nations: New York, NY, USA, 1999.

162. Regional Coordination Unit for the Caribbean-United Nations Environment Programme (UNEP-CAR/RCU). Improving the Management of Agricultural Pesticides in Colombia, Costa Rica and Nicaragua. Experiences of the GEF-Reducing Pesticide Run-Off to the Caribbean Sea Project; UNEP-CAR/RCU: Kingston, Jamaika, 2012.

163. Jiménez, P. SFE Pona a Disposición Nuevos Manuales de Buenas Prácticas Agrícolas para Arroz, Mango, Melón y Sandia; Servicio Fitosanitario del Estado (SFE): San José, Costa Rica, 2017.

164. Ramòn Rosales, J. Manual de Buenas Prácticas Agrícolas en el Cultivo de Frijol. Capacitación y Divulgación de Prácticas Agrícolas en el Caribe Nicaragüense para contribuir a la Reducción del Escurrimiento de Plaguicidas al Mar Caribe; MARENA: Managua, Nicaragua, 2010.

165. López Montes, J. Manual de Buenas Prácticas Agrícolas en el Cultivo de Tomate. Capacitación y Divulgación de Prácticas Agrícolas en el Caribe Nicaragüense para contribuir a la Reducción del Escurrimiento de Plaguicidas al Mar Caribe; Ministerio del Ambiente y los Recursos Naturales (MARENA): Managua, Nicaragua, 2010.

166. Lacayo Ortíz, J.J. Elaboración de Abonos Orgánicos y Biofertilizantes. Manejo Integrado de Malezas. Manejo Integrado de Plagas. Buenas Prácticas Agrícolas. Mejoras Prácticas de Manejo de Plaguicidas; Ministerio del Ambiente y los Recursos Naturales (MARENA): Managua, Nicaragua, 2010.

167. Corporación Bananera Nacional (CORBANA). Implementación de Buenas Prácticas Agrícolas para Reducir el Escurrimiento de Plaguicidas en el Cultivo de Banano de la Región Caribe Costarricense; CORBANA: San José, Costa Rica, 2011.

168. Díaz, A.; Gebler, L.; Maia, L.; Medina, L.; Trelles, S. Good Agricultural Practices for More Resilient Agriculture. Guidelines for Producers and Governments, Inter-American Program for the Promotion of Trade, Agribusiness and Food Safety; Embrapa, IICA: San José, Costa Rica, 2017; pp. 1-73, ISBN 978-92-9248-699-0.

169. Ministerio de Agricultura y Ganadería (MAG). Normativa para la Aplicación de Reconocimiento de los Beneficios Ambientales (RBA); MAG: San José, Costa Rica, 2010.

170. Ministerio de Agricultura y Ganadería (MAG). Estudio del Estado de la Producción Sostenible y Propuesta de Mecanismos Permanentes para el Fomento de la Producción Sostenible; MAG: San José, Costa Rica, 2010.

171. Baca Gutiérrez, S.; Lacayo Parajón, L.; Pastora Reyes, R. Estrategia de Fomento de la Certificación de Las Buenas Prácticas Agrícolas (BPA) a Partir de la Experiencia en los Departamentos de Matagalpa y Jinotega; Managua, Nicaragua, 2011. Available online: portalderevistas.upoli.edu.ni/index.php/acontecerd/article/download/ 135/86 (accessed on 11 April 2018).

172. Gazette. Law for the Promotion of Agro-Ecological and Ecological Agriculture No 765 (Ley de Fomento a la Producción Agroecológica u Orgánica); No 124; Gazette: Managua, Nicaragua, 2011.

173. Gazette. Law for the Development and Promotion of Organic Farming Activities No 8591 (Ley de Desarrollo, Promoción y Fomento de la Actividad Agropecuaria Orgánica; No. 155; Gazette: San José, Costa Rica, 2007.

174. Gazette. Regulation No 35242-MAG-H-MEIC to the Law No 8591 (Reglamento Para el Desarrollo, Promoción y Fomento de la Actividad Agropecuaria Orgánica); No 107; Gazette: San José, Costa Rica, 2012.

175. Tribunal Campesino. Informe Sobre los Retos Para la Implementación de un Proceso de Transición Desde la Agricultura Convencional Hacia una Agricultura Agroecológica en Nicaragua 2017; Tribunal Campesino: Managua, Nicaragua, 2017.

176. Rosemarin, A.; Ekane, N. The governance gap surrounding phosphorus. Nutr. Cycl. Agroecosyst. 2016, 104, 265-279. [CrossRef]

177. Azofeifa Rodríguez, R.; Ministry of Agriculture and Livestock of Costa Rica, San José, Costa Rica. Personal communication, 2016.

178. Riggs, P. Implication of New Research for the IPCC $1.5^{\circ}$ Special Report, with a Focus on Land Use; Pivot Point: San Francisco, CA, USA, 2018. 
179. Hrynkiewicz, K.; Baum, C. The Potential of Rhizosphere Microorganisms to Promote the Plant Growth in Disturbed Soils. In Environmental Protection Strategies for Sustainable Development; Malik, A., Grohmann, E., Eds.; Springer: Dordrecht, The Netherlands, 2012; pp. 35-64, ISBN 978-94-007-1591-2.

180. Matthews, A. The Common Agricultural Policy and development. In Research Handbook on Agriculture Law; McMahon, J.A., Cardwell, M.N., Eds.; Edward Elgar Publishing: Celtenham, UK, 2015; pp. 485-504, ISBN 978-1-78195462 1.

181. Watkins, K. Dumping on the World: How EU Sugar Policies Hurt Poor Countries; Oxfam International: Oxford, UK, 2004; ISBN 9781848143265. 